\title{
PENERAPAN PENDEKATAN CREATIVE PROBLEM SOLVING UNTUK MENINGKATKAN KEMAMPUAN KONEKSI MATEMATIS SISWA
}

\author{
Nurul Akmal ${ }^{1}$, Edy Saputra ${ }^{2}$ \\ ${ }^{1}$ IAIN Lhokseumawe \\ nurulakmal1991@gmail.com \\ ${ }^{2}$ STAIN Gajah Putih Takengon \\ edysaputra.esa@gmail.com
}

\begin{abstract}
ABSTRAK
Penelitian ini fokus pada peningkatan kemampuan koneksi matematis siswa. Metode penelitian yang digunakan adalah desain quasi experiment jenis pretest-posttest group design. Pengambilan sampel dilakukan secara purposive sampling sehingga terpilih 39 orang siswa kelompok eksperimen dan 37 orang siswa kelompok kontrol pada kelas VIII SMP Negeri 1 Lembang Kabupaten Bandung Barat. Tujuan penelitian ini adalah untuk melihat peningkatan kemampuan koneksi matematis siswa setelah diajarkan dengan pendekatan Creative Poblem Solving pada kelas ekperimen dan peningkatan kemampuan koneksi matematis siswa setelah diajarkan dengan pendekatan biasa pada kelas kontrol. Analisis data dengan uji Mann Whitney untuk melihat peningkatan kemampuan koneksi matematis. Hasil analisis menunjukkan bahwa peningkatan kemampuan koneksi matematis siswa yang memperoleh pembelajaran dengan pendekatan Creative Problem Solving lebih baik daripada siswa yang memperoleh pembelajaran biasa.
\end{abstract}

Kata Kunci: pendekatan creative problem solving, kemampuan koneksi matematis

\begin{abstract}
This study focuses on enhancement mathematical connection ability students. The method used is a quasi-experimental design with pretest-posttest control group. Samples were taken by purposive sampling technique that was selected 39 experimental group students and 37 control group students from class $8^{\text {th }}$ SMP Negeri 1 Lembang, West Bandung. The purpose of this study is to see an enhancemen mathematical connection ability after experimental class taught by Creative Problem Solving approch and control class taught by the usual approach. Data were analyzed by Mann Whitney test to see an enhancemen mathematical connection ability. The analysis showed that enhancemen of students mathematical connection ability who was taught by Creative Problem Solving approach is better than the students who was taught by the usual learning.
\end{abstract}

Keyword: creative problem solving approach, mathematical connection ability

\section{PENDAHULUAN}

Matematika merupakan ilmu yang universal yang mendasari perkembangan teknologi modern. Matematika juga mempunyai peran penting dalam berbagai disiplin ilmu dan memajukan daya pikir manusia. Dalam pembelajaran matematika, materi yang satu merupakan prasyarat dari materi yang lainnya atau konsep yang satu diperlukan untuk 
menjelaskan konsep yang lainnya. Sebagai ilmu yang saling berkaitan, dalam hal ini siswa diharapkan memiliki kemampuan untuk memecahkan persoalan-persoalan matematika yang memiliki kaitan terhadap materi yang dipelajari sebelumnya. Kemampuan ini disebut dengan kemampuan koneksi matematis.

Kemampuan koneksi matematis adalah salah satu kemampuan yang harus dimiliki oleh setiap siswa. Pentingnya memiliki kemampuan koneksi matematis terkandung dalam tujuan pembelajaran matematika sekolah menengah (KTSP, 2006, NCTM, 1989), yaitu: memahami konsep matematika, menjelaskan keterkaitan antar konsep dan mengaplikasikan konsep atau algoritma secara luwes, akurat, efisien, dan tepat dalam pemecahan masalah.

Kenyataan yang terjadi di lapangan menunjukkan bahwa kemampuan koneksi matematis siswa belum baik. Hal ini ditunjukkan oleh hasil penelitian Permana dan Sumarmo (2007) yang menyatakan bahwa kemampuan koneksi matematis siswa yang mendapatkan pembelajaran biasa tergolong kualifikasi kurang. Hal tersebut serupa dengan hasil penelitian yang dilakukan oleh Fauzi (2011) walaupun secara keseluruhan kemampuan koneksi matematis terjadi peningkatan tetapi peningkatan berada pada kualifikasi kurang. Hal tersebut terlihat dari hasil penelitian yang menunjukkan kemampuan koneksi matematis siswa melalui pendekatan pembelajaran Metakognitif memperoleh nilai rata-rata sebesar 29,045 sebelumnya 9,375 (N-Gain KKM sebesar 0,326), sementara siswa yang memperoleh pembelajaran biasa atau konvensional memperoleh rata-rata kemampuan koneksi matematis sebesar 24,782 sebelumnya 9,316 (N-Gain KKM sebesar 0,279).

Linto, dkk (2012) menyatakan bahwa dalam pembelajaran terlihat siswa masih sulit menghubungkan materi yang sedang mereka pelajari dengan materi prasyarat yang sudah mereka pelajari, konsep-konsep yang telah dipelajari tidak bertahan lama dalam ingatan siswa sehingga mengakibatkan kemampuan koneksi matematis siswa belum optimal. Kondisi ini terjadi dikarenakan pada proses pembelajaran siswa bukan memahami materi tetapi menghafal materi sehingga ketika materi lanjutannya perlu dikoneksikan dengan materi sebelumnya akan menghambat kemampuan berpikir siswa. Zulmaulida (2018) menyatakan pembelajaran tidak bertujuan hanya untuk menghafal sesuatu tetapi juga memberikan pemahaman penuh sehingga pembelajaran menjadi bermakna. Jika pembelajaran hanya fokus pada menghafal sesuatu, itu akan dilupakan ketika materi lain diajarkan oleh guru. Berdasarkan dari beberapa penjelasan di atas, dapat dikatakan bahwa kemampuan koneksi matematis siswa belum memadai. Oleh karena itu, kemampuan 
koneksi matematis siswa penting untuk dikembangkan dan ditingkatkan.

Salah satu upaya untuk meningkatkan kemampuan koneksi matematis siswa adalah dengan menemukan sebuah pendekatan pembelajaran yang sesuai dan mampu mendukung semua aspek tersebut. Pembelajaran Creative Problem Solving merupakan pembelajaran yang berpusat pada pengajaran dan keterampilan kreatif pemecahan masalah, yang diikuti dengan penguatan keterampilan (Pepkin, 2004). Menurut Sari (2013) pembelajaran dengan pendekatan Creative Problem Solving berusaha mengaitkan konten mata pelajaran dengan situasi dunia nyata dan memotivasi siswa menghubungkan pengetahuan yang dimiliki dengan kehidupan mereka sehari-hari dan diperkuat dengan peningkatan kreativitas.

Noortsani (2013), Nur (2014), dan Suhendra (2014) menyatakan bahwa pendekatan Creative Problem Solving dapat meningkatkan kemampuan pemecahan masalah, kemampuan komunikasi dan hasil belajar siswa dibandingkan dengan pembelajaran langsung. Dari beberapa pendapat yang telah dikemukakan menunjukkan bahwa pendekatan Creative Problem Solving dapat meningkatkan kemampuan kognitif siswa. Model Creative Problem Solving terdiri dari tahap klasifikasi masalah, pengungkapan pendapat, evaluasi dan seleksi, serta implementasi (Pepkin, 2004). Vidal (2010) menyatakan bahwa ada lima tahap pelaksaan dari pendekatan Creative Problem Solving yaitu: 1) Menemukan fakta: yaitu mengobservasi secara hati-hati dan objektif, seperti kamera yang mengumpulkan informasi tentang situasi permasalahan. Mengembangkan dan mengidentifikasi fakta dari sebuah situasi; 2) Menemukan masalah: mengklarifikasi tantangan atau situasi permasalahan melalui penyediaan cara yang berbeda dan membuat refleksi dari situasi; 3) Menemukan gagasan: mencari lebih banyak ide, alternatif, pilihan, cara, dan pendekatan, menggunakan berbagai metode dan teknik (berpikir secara berbeda); 4) Menemukan solusi: memeriksa ide-ide dengan cara yang berbeda dari suatu kejadian, sudut pandang dan kriteria, lebih paham tentang konsekuensi, implikasi, dan reaksi untuk solusi yang lebih bagus. Memilih atau mengkombinasikan ide-ide untuk membuat rencana dari tindakan (berpikir secara luas); 5) Menemukan penerimaan: mengembangkan rencana dari tindakan, mempertimbangkan semua peserta yang harus menerima rencana yang telah dilakukan. Mencari jalan dari pembuatan solusi atau ide sehingga lebih mudah dikerjakan, dapat diterima, lebih efektif, dan lebih menguntungkan.

Tahapan-tahapan yang dikemukakan di atas menunjukkan bahwa pendekatan Creative Problem Solving bisa dijadikan salah satu alternatif pendekatan pembelajaran yang tepat digunakan untuk meningkatkan kemampuan koneksi matematis siswa. Tahapan yang dilakukan selama pembelajaran mengkondisikan siswa untuk dapat mengkoneksikan 
pengetahuan yang sudah ada sebelumnya untuk mengnkonstruksi pengetahuan baru pada sub materi lanjutannya. Oleh karena itu penelitian ini meninjau aspek pembelajaran dan kemampuan koneksi matematis siswa.

\section{METODE PENELITIAN}

Penelitian ini adalah penelitian kuantitatif dengan desain quasi experiment jenis pretest-posttest group design. Saputra (2018) mendesain rancangan penelitian/desain kuasi eksperimen dengan grup pretes-postes seperti pada Tabel 1.

Tabel 1. Desain Penelitian

\begin{tabular}{cccc}
\hline Kelompok Perlakuan & Pretest & Perlakuan & Postest \\
\hline Eksperimen & $\mathrm{O}_{1}$ & $\mathrm{X}$ & $\mathrm{O}_{2}$ \\
Kontrol & $\mathrm{O}_{1}$ & & $\mathrm{O}_{2}$ \\
\hline
\end{tabular}

Arikunto (2010) menyatakan bahwa populasi adalah keseluruhan subjek penelitian. Sampel adalah sebagian atau wakil populasi yang diteliti (Arikunto, 2010). Polpulasi dalam penelitian ini adalah seluruh siswa kelas VIII SMP Negeri 1 Lembang Kabupaten Bandung Barat. Pengambilan sampel dilakukan dengan purposive sampling, sampel dari penelitian ini adalah dua kelas yang mempunyai kemampuan relatif yang sama yaitu kelas VIII E dan kelas VIII I.

Kelas VIII E dijadikan sebagai kelas eksperimen yang mendapatkan pembelajaran dengan menggunakan pendekatan Creative Poblem Solving. Kelas VIII I adalah kelas kontrol yang mendapatkan pembelajaran biasa. Instrumen yang digunakan dalam penelitian ini adalah instrumen tes dengan bentuk esai. Soal disusun sesuai dengan indikator yang akan dilihat pada kemampuan koneksi matematis seperti yang telah dipaparkan sebelumnya. Adapun indikator kemampuan koneksi dalam penelitian ini adalah kemampuan untuk memecahkan masalah matematika dengan menghubungkan konsepkonsep antar matematika, menghubungkan konsep matematika dengan konsep disiplin ilmu lain, dan menghubungkan konsep matematika dengan kehidupan sehari-hari.

Soal kemampuan koneksi matematis diberikan dua kali pada siswa kelas eksperimen yang mendapatkan pembelajaran dengan pendekatan Creative Problem Solving dan kelas kontrol yang mendapatkan pembelajaran biasa yaitu pada pertemuan pertama sebelum diberikan perlakuan dan pada pertemuan terakhir setelah diberikan perlakuan. Hal tersebut dilakukan karena tujuan penelitian ini adalah untuk melihat peningkatan kemampuan koneksi siswa setelah diberikan perlakuan. Pemberian nilai atau skor siswa menggunakan sebuah pedoman penskoran yang disebut holistic scale dari North Carolina 
Department of Public Instruction dengan poin 0, 1, 2, 3 dan 4.

Tabel 2. Pedoman Pemberian Skor Soal Koneksi Matematis

\begin{tabular}{ll}
\hline \multicolumn{1}{c}{ Respon siswa terhadap soal } & Skor \\
\hline Tidak ada jawaban, kalaupun ada hanya memperlihatkan ketidakpahaman tentang konsep sehingga informasi & 0 \\
yang diberikan tidak berarti apa-apa & \\
Hanya sedikit dari jawaban yang benar & 1 \\
Penjelasan secara matematis masuk akal, namun hanya sebagian lengkap dan benar & 2 \\
Penjelasan secara matematis masuk akal dan benar, meskipun tidak tersusun secara logis atau terdapat sedikit \\
kesalahan bahasa \\
Penjelasan secara matematis masuk akal dan jelas serta tersusun secara logis dan sistematis \\
\hline
\end{tabular}

Skor atau nilai yang akan digunakan untuk melihat peningkatan kemampuan koneksi matematis siswa sebelum dan sesudah pembelajaran adalah nilai gain ternormalisasi. Soal kemampuan koneksi yang telah diujikan pada kedua kelas, selanjutnya data diuji kenormalitasnya dengan menggunakan Q-Q plot dan uji Kolmogorov-Smirnov pada pada taraf signifikansi 0,05 berbantuan program SPSS 17.0 for windows. Data tidak berdistribusi normal pada pembelajaran Creative Problem Solving dan berdistribusi normal pada pemebelajaran biasa sehingga dilanjutkan dengan uji perbedaan dua rata-rata dengan menggunakan uji statistik nonparametrik yaitu uji Mann-Whitney $U$.

\section{HASIL DAN PEMBAHASAN}

Hasil deskripsi nilai kemampuan koneksi matematis siswa kelas eksperimen yang mendapatkan pembelajaran dengan menggunakan pendekatan Creative Problem solving dan siswa kelas kontrol yang mendapatkan pembelajaran biasa dengan bantuan program SPSS 17.0 for windows ditampilkan pada Tabel 3.

Tabel 3. Deskripsi Nilai $N$-Gain Kelas Eksperimen dan Kelas Kontrol

\begin{tabular}{lcc}
\hline Kelas & Statistik & Skor \\
\hline Creative Problem Solving & $\mathrm{N}$ & 39 \\
& $\bar{x}$ & 0,78 \\
Biasa & Kriteria & Tinggi \\
& $\mathrm{N}$ & 37 \\
& $\bar{x}$ & 0,54 \\
& Kriteria & Sedang \\
\hline
\end{tabular}

Pengujian hipotesis diawali dengan pengujian normalitas pada nilai $\mathrm{N}$-gain masingmasing kelas. Pengujian normalitas menggunakan uji statistik Kolmogorov-Smirnov dengan taraf signifikan $\alpha=0,5$ pada nilai $N$-Gain kemampuan koneksi matematis siswa akan diperlihatkan pada Tabel 4.

\begin{tabular}{lcccc} 
Tabel 4. Uji Normalitas N-Gain Kemampuan Koneksi Matematis Siswa \\
\cline { 2 - 4 } Kelas & \multicolumn{3}{c}{ Kolmogorov-Smirnov } & \multirow{2}{*}{ Ket. } \\
\cline { 2 - 3 } & Statistic & $d f$ & Sig. & \\
\hline $\begin{array}{l}\text { Creative Problem } \\
\text { Solving }\end{array}$ & 0,146 & 39 & 0,036 & $\begin{array}{l}\text { Tidak Berdistribusi } \\
\text { Biasa }\end{array}$ \\
0,088 & 37 & 0,2 & $\begin{array}{l}\text { Bermal } \\
\text { Berdistribusi } \\
\text { Normal }\end{array}$ \\
\hline
\end{tabular}

Tabel 4 menunjukkan bahwa nilai Sig. kelas eksperimen yang mendapatkan 
pembelajaran dengan pendekatan Creative Problem Solving yaitu 0,036. Nilai tersebut lebih kecil dari $\propto=0,05$, dengan demikian skor $N$-gain kemampuan koneksi matematis siswa kelas eksperimen tidak berdistribusi normal. Sedangkan nilai Sig. kelas kontrol yang mendapatkan pembelajaran biasa yaitu 0,2 . Nilai tersebut lebih besar dari $\propto=0,05$, dengan demikian skor $\mathrm{N}$-gain kemampuan koneksi matematis siswa kelas kontrol secara keseluruhan berdistribusi normal. Karena tidak semua kelas memiliki data yang berdistribusi normal maka dilakukan uji Mann-Whitney untuk melihat perbandingan dua rata-rata dengan hasil sebagai berikut.

Tabel 5. Uji Perbedaan Dua Rata-rata Skor $N$-gain

\begin{tabular}{ccccc}
\hline & \multicolumn{2}{c}{ Statistik } & Keterangan \\
\cline { 1 - 3 } Mann- Whitney $U$ & $Z$ & Asymp. Sig. (2-tailed) & $\begin{array}{c}\text { Asymp. Sig. (1- } \\
\text { tailed) }\end{array}$ & \\
193,000 & $-5,497$ & 0,000 & 0,000 & $\mathrm{H}_{0}$ Tolak \\
\hline
\end{tabular}

Hasil uji perbedaan dua rata-rata menunjukkan nilai sig. 0,000 lebih kecil dari $\propto=$ 0,05 dengan demikian rata-rata skor $\mathrm{N}$-gain kemampuan koneksi matematis siswa kelas eksperimen yang mendapatkan pembelajaran dengan pendekatan Creative Problem Solving lebih baik daripada siswa kelas kontrol yang mendapatkan pembelajaran biasa. Dengan demikian dapat disimpulkan bahwa peningkatan kemampuan koneksi matematis siswa yang memperoleh pembelajaran dengan pendekatan Creative Problem Solving lebih baik daripada siswa yang memperoleh pembelajaran biasa.

Penelitian dengan hasil serupa dilakukan oleh Purnamasari (2014) menyatakan bahwa peningkatan kemampuan koneksi matematis siswa yang mengikuti pembelajaran kooperatif lebih baik dari siswa yang mengikuti pembelajaran langsung. Hal tersebut terjadi karena pembelajaran dengan menggunakan pendekatan Creative Problem Solving melatih siswa dalam memecahkan masalah dalam matematika. Hasil penelitian Purwati (2015) menyatakan bahwa kemampuan pemecahan masalah matematis siswa kelas eksperimen yang menggunakan pendekatan Creative Problem Solving lebih baik dari pada siswa kelas kontrol yang yang memperoleh pembelajaran langsung. Salah satu kelebihan yang diungkapkan Djamarah (Siswadi, dkk, 2010) adalah pendekatan Creative Problem Solving dapat membuat pendidikan di sekolah menjadi lebih relevan dengan kehidupan. Hal tersebut juga memberikan dampak yang besar bagi siswa dalam mengembangkan kemampuan koneksi matematisnya.

\section{KESIMPULAN}

Hasil penelitian memberikan kesimpulan bahwa peningkatan kemampuan koneksi matematis siswa yang memperoleh pembelajaran dengan pendekatan Creative Problem 
solving lebih baik daripada siswa yang memperoleh pembelajaran biasa. Pembelajaran dengan menggunakan pendekatan Creative Problem Solving memberikan dampak yang baik dalam pengembangan kegiatan belajar mengajar. Pembelajaran dengan menggunakan pendekatan Creative Problem Solving direkomendasikan kepada guru untuk diterapkan di sekolah.

\section{REFERENSI}

Arikunto, S. (2010). Prosedur penelitian. Cetakan Keempat Belas. Jakarta: RinekaCipta.

Fauzi, M. A. (2011). Peningkatan kemampuan koneksi matematis dan kemandirian belajar siswa dengan pendekatan pembelajaran metakognitif di sekolah menengah pertama. Proceeding at International Seminar and the Fourth National Conference on Mathematics Education. ISBN: 978-979-16353-7-0

NCTM. (1989). Curriculum and evaluation standard for school mathematics. (http://www.mathcurriculumcenter.org/PDFS/CCM/summaries/standards_summary .pdf. diakses 25 September 2017)

Noortsani, I. (2013). Peningkatan kemampuan pemahaman dan pemecahan masalah matematis siswa SMA di kapupaten cianjur melalui pendekatan creative problem solving. Tesis Pendidikan Matematika Universitas Pendidikan Indonesia. Bandung: tidak diterbitkan.

Nur, A. M. (2014). Penerapan pembelajaran IPA terpadu tipe threaded dan neated dengan model creative problem solving untuk meningkatkan keterampilan pemecahan masalah dan berpikir kreatif siswa MTsN. Tesis Pendidikan Matematika Universitas Pendidikan Indonesia. Bandung: tidak diterbitkan.

Permana, Y., dan Sumarmo, U. (2007). Mengembangkan kemampuan penalaran dan koneksi matematik siswa SMA melalui pembelajaran berbasis masalah. Educationist. Vol. I No.2. ISSN: 19078838

Pepkin. (2004). Creative problem solving in math. (http//www.uh.edu.hti/cu/2004/v02/04.htm, diakses 14 september 2017)

Purnamasari, Y. (2014). Pengaruh model pembelajaran kooperatif tipe teams games tournament (TGT) terhadap kemandirian belajar dan peningkatan kemampuan penalaran dan koneksi matematik peserta didik SMPN 1 kota tasikmalaya. Jurnal Pendidikan dan Keguruan, Vol. 1 No. 1, 2014

Purwati. (2015). Efektifitas pendekatan creative problem solving terhadap kemampuan pemecahan masalah matematika pada siswa SMA. Jurnal Ilmiah Edukasi Matematika (JIEM). Vol. 1/No.1/april 2015 ISSN: 977-2442-8780-11

Saputra, E. (2018). The enhancement of spatial levels reviewed from students' cognitive styles. (http://iopscience.iop.org/article/10.1088/17426596/1028/1/012093/meta, diakses Juni 2018)

Sari, R. M. M. (2013). Pengaruh pendekatan creative problem solving (CPS), problem solving (PS), dan direct instruction (DI), terhadap peningkatan kemampuan koneksi matematis siswa SMP. Tesis Pendidikan Matematika Universitas Pendidikan Indonesia. Bandung: tidak diterbitkan.

Siswadi, I. P., dkk. (2014). Pengaruh model pembelajaran creative problem solving (cps) berbantuan media grafis terhadap hasil belajar IPA siswa kelas V SD gugus VI pangeran diponogoro denpasar barat tahun ajaran 2013/2014. Jurnal Mimpar PGSD Universitas Pendidikan Ganesa Jurusan PGSD. Volume 2 Nomor 1

Suhendar, A. (2014). Penerapan model pembelajaran creative problem solving untuk 
meningkatkan hasil belajar siswa pada aplikasi pengolah angka. Tesis Pendidikan Matematika Universitas Pendidikan Indonesia. Bandung: tidak diterbitkan.

Vidal, R. V. V. (2010). Creative problem solving: an applied university course. Jurnal Pesquisa Operational. Volume 30, number 2,p.405-426, ISSN: 0101-7438

Zulmaulida, R. (2018). Watson-Glaser's Critical Thinking Skills. (http://iopscience.iop.org/article/10.1088/1742-6596/1028/1/012094/meta, diakses Juni 2018) 